\title{
Definition and Determination in Medieval Arabic Grammatical Thought
}

\author{
Manuel Sartori
}

\section{$1 \quad$ Introduction}

The grammatical tradition of Arabic may seem to be based entirely on the oldest grammar book to have reached us, the Kitāb of Sïbawayhi (d. 180/796?), its later development being nothing more than a reinterpretation and/or a reorganization of this first material. Yet, fundamental and significant additions have been brought to bear on this first and crucial work. Suffice it to mention here the category of 'inša', which emerged in the post-Classical period of Arabic grammar (after the first half of the $5 \mathrm{TH} / 11 \mathrm{TH}$ century), probably as the result of influence from the legal sciences.1

The term 'inš $\bar{a}$ ' is not the only one to have remained unrecognized for a long time. This is also the case of tahșiș, usually rendered by 'particularization' which, without being totally unknown, has remained largely unrecognized. It has been shown to appear in Arabic grammar relatively late, around the end of the 4тн/10тн century. Its first occurrences are in the form of nouns derived from the consonantal root hy-ș-ș, first in the form of ihtișāss with al-Sīräfì (d. 368/979), then of muhassșiș with 'Abū 'Alī al-Fārisī (d. 377/987). The term tahșiș itself appears with Ibn al-Warrāq (d. 381/991), similar in sense to its later use, but it is primarily with Ibn Jinnī (d. 392/1002), then with 'Abd al-Qāhir al-Jurjānī (d. 471/1078), and especially with al-Zamahšarī (d. 538/1144) that tahșịș acquires its technical and grammatical meaning of 'particularization'.2

After studying the term tahșịș, I turn to the term tahlīṣ that occurs in combination with it, in order to specify the time of its appearance, and then we analyze the terminological distributions in connection with the opposition definition/indefinition (ta'riff/tankirr) in Arabic. First, we shall take a look at the concepts of definition/indefinition and determination/indetermination.

1 On the origin of the 'inšă 'category, see Larcher's articles, republished in Larcher (2014).

2 For these historical data and the technical sense of tahșiș, see Sartori (2018). 
Two pairs of notions should be effectively and logically distinguished on the following basis: all that is definite is determinate, but all that is determinate is not necessarily definite. 3 In this context, the terms of the first pair, definition/indefinition, refer to definite and indefinite expressions. An example of an indefinite and indeterminate expression is man, i.e. a single noun devoid of any marker of definition or determination. From there, a move towards definition begins: $a$ $m a n$ is an indefinite and determinate expression (here by a quantification, the article $a$, which is an indefinite determiner), while a tall man or amanof science remain indefinite expressions, which are, however, more determinate than the first one (fortheyhavea quantification, $a$, and a qualification, tallor ofscience). These expressions are not yet as definite as the man, which by itself is a definite expression (where the article the is a definite determiner). This expression is then both definite and determinate. However, it is less determinate than for example the tall man, which adds a determination (tall or the man of science) for the same reasons.

In Arabic, the pair definition/indefinition is identified easily with that of

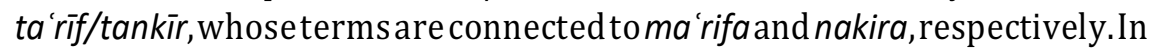
Arabicterminologyma 'rifa is a 'definite expression', while nakira is an 'ind efinite expression'. The definite term in Arabic is so either by nature (e.g., a proper namelikeZayd), or by the article (al-rajul) or by annexation (rajulal-madina). As for the indefinite term, whereas in English a term may be indefinite and indeterminate ( $m a n$ ), in Arabic a term is minimally determinate since rajul equals 'a man' and not 'man'.

Intechnicalterms, indefinitionis thus tankirand definition ta' riff.Could itbe the case that tahșiș, whose meaning is 'particularization', is a form of determination? This is precisely the question that the present article wishes to answer.

\section{Tahșīṣ and Its Complementary Term}

\subsection{The Technical Sense of tahșịs in Arabic Grammar}

As 'particularization', tahșiș is not entirely unknown in the secondary literature. However, when it appears, it is always incidentally, no special section being dedicated to it. This is the case of Wright (since it is an addition made by Wright

3 Which opposes the scheme proposed by Kouloughli(2001:40), who claims that a definite term can at the same time be indeterminate. 
in a footnote, it does not derive from Caspari, see Sartori 2018: 205, n. 5), Reckendorf, Gätje, Fleisch, Troupeau, Carter, Badī' Ya'qūb and 'Āṣī, and Brustad.4 One even finds the concept referred to without the term in the articles iḍāfa and specificity of the Encyclopedia of Arabic language and linguistics.5 In the vast majority of cases, the term and its technical scope are ignored.6

On the basis of the scattered data I have collected the following may be said about the technical meaning of the word: tahșiș appears in connection with semantic annexation ('id̄âfa ma'nawiyya), with qualification ( nat $^{\prime}$ ), and even in connection with the explanatory apposition ('aț bayān), albeit merely as an extension of qualification in Ibn Mālik (d. 672/1274) (Šarḥ I, 533; see Sartori 2018).

Regarding tahșiș, Carter speaks of a "weaker type of definition". For Wright it is a "partial determination", and for Reckendorf a nähereBestimmung (almost determination/definition).7 Apparently, tahșiș is assigned two significations (determination and definition), which it would seem useful to distinguish.8 For reasons to be explained below, confusing the two leads to inadequacy. It seems that Arab grammarians were aware of a distinction to be made between definition and determination. Suffice it for now to say that as a technical term, tahșiș has the meaning of particularizing an indefinite term by another one,

4 See Wright (1996:II, 198D, 199A, 260-261D); Reckendorf (1921:57, 193, 200, 218); Gätje (1970:221, 235); Carter (1981:377, 461); Fleisch (1986:1008B); Badī` Ya'qūb and 'Āṣī (1987:I, 154, 367, II, 868, 1254); Troupeau (1993:1034a); Carter (2000:241B); Brustad (2000:21).

5 See Ryding and Versteegh (2007:295b), Hoyt (2009:316B).

6 See Silvestre de Sacy (1831); Forbes (1863); Palmer (1874); Socin (1885); Vernier (1891); Howell (1911); Fleisch $(1961,1979)$, and finally Blachère and Gaudefroy-Demombynes (1975). Regarding recent grammars of Arabic, it is still completely absent. See Cantarino (1974); Kouloughli (1994); Neyreneuf and Al-Hakkak(1996); Badawi etal.(2004); Buckley (2004); Holes (2004); Alosh (2005); Ryding (2005); Hassanein (2006); McCarus (2007); Imbert (2008); Schulz etal. (2008); El-Ayoubi et al. (2010).

7 See Carter (2000:241B); Wright (1996:II, 261D); Reckendorf (1921:200). German dictionaries indicate that Bestimmung means both 'definition' and 'determination', which demonstrates its vagueness from a terminological point of view.

8 The confusion between definition/indefinition and determination/indetermination is fairly common. Some authors speak of Determination und Indetermination for ta 'rif and tankirand of Qualifikation for tahșiș (see Gätje 1970: 226). This is also the case with Wensinck (1931), whose study is entitled "The article of determination in Arabic", whereas Heselwood and Watson (2015) speak of "The Arabic definite article". As noted by Jan Retsö, "they [the FrancoGerman school] use the term 'indetermination' variously for indefiniteness, non-definiteness (or both), 'indefinite article', or the ending - $n$ ", where he distinguishes between "non-definite" = indefinite and indeterminate (e.g. house) and "indefinite" = indefinite and determinate (e.g. a house) (Retsö 1986:342 f.). One can regret with Pierre Larcher that the terms of the couple ta 'riff/tankīr are renamed "détermination" and "indétermination" in Arabist grammars (see Larcher 1991:146, n. 18). See also Kouloughli (2001, especially 39f.). 
itself indefinite, whether it is the second term of an annexation (zāranī rajulu falsafatin 'a man of philosophy paid me a visit'), or a qualifier in the broadest sense of the term, that is to say, an attributive adjective (rajulun țawilun 'a tall man'), including qualifying clauses (rajulun yaktubu risālatan 'a man who writes a letter') and prepositional phrases (rajulun min banī tamimin 'a man from the Banū Tamīm'), or an explanatory apposition (ištaraytu halyan siwāran 'I bought jewelry, a bracelet'). 9 In this sense, tahșiș, without being properly speaking intermediate to tankir/ta'riff, is connected with these terms, according to a suggestion made by the rhetorician al-Qazwinī (d. 739/1338), for whom "the completion of the particularization is [made] by definition" (al-tahșiș kamāluhu bi-l-ta'rif, 'Ị̇āh 41). From this reading, it is possible to understand those of Wright, Reckendorf and Carter. In this sense, tahșiș, as 'particularization', would indeed be a form of 'determination'.

\subsection{The Complementary Terms to tahșị}

While the technical term tahșiș was not entirely unknown, the situation is different for its complementary terms, which are nowhere treated in the secondary sources cited above, nor in the primary sources.

\subsubsection{Taḩliș}

The first appearance of a term used as complementary to tahșiș in its technical sense is apparently in Ibn Jinnī's Hașā'iș (I,392), when he speaks aboutthe different case endings in the expression bi-smi llāhil-raḥmānu/al-rahịmu/a:

and this is because when [the noun] Allāh is qualified, the goal is not to define it by what follows in terms of qualifiers, since concerning this name there is no doubt that it would need to be qualified in order to specify it, for it is the name of one with whom no-one is associated [...]. Thus, since it is not exposed to doubt, its qualification does not intervene in order to specify, but to praise Allāh [...], and so making it follow its declension formallytakes the same course as that what follows for purposes of specification or particularization (wa-dālika 'anna Allāh ta 'älā 'idāa wușifa fa-laysa l-ġaraḍ fi d̂ā lika ta' rîfahu bi-mā yatba uhu min șifatihi li-'anna hād̄ā I-ism lā ya tariọu šakk fihi fa-yahtāja 'ilā wașfihi li-tahlīṣihi li-'annahu l-ism al ladī lā yušāraku fihi 'alā wajh wa-baqiyyat 'asmā'ihi'azza wa-jalla-ka-l-'awșāfal-tābi'a li-hād̄āl-ism wa-'id̄a lam ya tariộ šakk fïhilam taji'șifatuhu li-tahlīșihiballi-l-țanā' alāllāhta'ālā [...] wa-d̄ālika 'anna'itbā ahu'i'rābahujārinfïl-laf̣̦ majrāmāyatba 'li-I-tahlīṣwa-l-tahșịș)

9 See about these points Sartori (2018). 
The term tahlisș 'specification,'10 here is used by the same author along with tahșiș in a passage related to qualification (Hașāiiș II, 146, see also II, 447): "and this is because qualifications in speech are of two types, either for specification and particularization, or for praise and eulogy" (wa-d̄ālika 'anna l-șifa fĩ l-kalām 'alā ḍarbayn 'immā li-I-tahlīṣ wa-l-tahșịș wa-'immā li-I-madḥ wa-l-țanā'). Nevertheless, it is not yet possible to comprehend either term in a very precise way since Ibn Jinni does not say more than this. Thus, the only certain thing is that these two terms operate together at the level of qualification.

The term tahlīș is absent from Sībawayhi's Kitāb,11 appearing for the first time in al-Mubarrad's (d. 285/898) Muqtadab, and later in al-Zajjājì's (d. 337/949) Kitāb al-lāmāt in a non-technical sense, without any connection either with tahșiss, or with annexation or qualification.12 At the same time as Ibn Jinni,13 we find tahșiș in Ibn Fāris (d. 395/1004), once again in connection with adjectives (Șāḥibī 52):

The adjective follows two courses. One of them is to distinguish a noun from a noun, as when we say zaydun al-'ațtāru 'Zayd the perfumer' and zaydun al-tamimiyyu 'Zayd the Tamimite', distinguishing it by means of its adjective from others sharing the same name. The other [course] has the meaning of praise and of blame, like al-'aqqil 'the judicious' and al-jāhil 'the ignorant' (wa-l-na 't yajrī majrayayn 'a haduhumā tahlīș ism min ism ka-qawlinā zaydun al-'ațțāru wa-zaydun al-tamimiyyu hallașnāhu bi-na tihi min allad̄ī šārakahu fĩ ismihi wa-l-'āhār 'alā ma 'nā I-madḥ wadamm naḥwa al-'āqilwa-l-jāhil)

In the examples produced by Ibn Fāris, the aim is indeed to complete a definite term (here thepropernameZayd) by aterm thatitselfis definite (al-'ațtārand al-tamìmi).

10 I have chosen this translation for the term in order to retain the etymology of Latin species, which denotes an element within a class at a lower level/from a lower level, on the understanding that a species, i.e. an element within a class, is less general than the class itself and thusismore definite, which is what is at stake with concepts of tahlīṣ (and tahșiș, and so on).

11 Troupeau (1976:85) records only one occurrence each of hallașa and ḩallașa min, the former in the sense of 'to clarify', the latter in that of 'to get free from'.

12 See Mubarrad, Muqtadab II, 567 and Zajjājī, Lāmāt 114.

13 The appearance, at that time, of these words is a striking manifestation of the introduction of logic in the Arab world. This is true of tahliș understood as 'specification' (i.e., from genus to species). 
In this connection it is important to note that in other authors, particularly in the family of treatises related to al-Zajjājì's Jumal, tahlīs, as a single term, is replaced by a noun phrase from the root $s$-r- $k$, whose trace is found in the quotation from Ibn Fāris cited above. This is the case of Ibn Harüf (d. 609/1212), who uses the expression raf' al-ištirāk 'to remove the equivocity' in connection with nat (Šarh I, 300):14 "The adjective serves to particularize the indefinite expression and to remove the supposed equivocity concerning the definite qualified expression" (wa-fāidatal-na't tahșịs al-nakira wa-raf' al-ištirāk al-mutawahham fí l-man'ūt al-ma'rifa). In a similar context, Ibn 'Ușfūr (d. 669/1271) uses the expression 'izālat ištirāk (Šarḥ I, 142): "According to the grammarians, the adjective designates a noun or what equals a noun that follows what precedes it in order to particularize an indefinite expression or to dispel the possible equivocity of a definite expression" (al-na't 'inda al-nahwiyyin 'ibāra 'an ism 'aw mā huwa fĩ taqdīr ism yatba'u mā qablahu li-tahșịș nakira 'aw li-'izālat ištirāk 'ārid fī ma'rifa).15

The transition is found in the writings of 'Alī ibn Muhammad al-Jurjānī al-Sayyid al-Šariff (d. 816/1413), in which the same identification of the phenomenon is present, but with a different term. He writes (Ta'rifāt 73): "Clarification denotes the fact of removing the ellipsis that happens in definite expressions" (al-tawḍīh 'ibāra 'an raf' al-'ị̣̂mār al-ḥāșil fĩ l-ma'ārif).

\subsubsection{Tawdīh}

After Ibn Fāris, tahliș apparently disappears in favor of tawdịh 'clarification'.16 Its first occurrence is in 'Abd al-Qāhir al-Jurjānī (d. 471/1078). Dealing with qualifiying praise, in particular praise reserved for Allāh, he writes (Dalāil 44), following Ibn Jinni: "To qualification belongs that qualification which contains neither particularization nor clarification" (wa-'anna min al-șifa șifa lā yakūnu

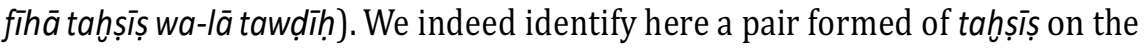
one hand and of tawdith on the other instead of tahliș. The author is even more precise about the adjective in his Šarḥ al-Jumal (Šarḥ 276, see also Muqtașid II, 175):

14 'Polysemy' in linguistics (see Larcher 2011:307, n. 4), is what in logic is called 'equivocity'.

15 In Ibn 'Ușfūr, tahliș does not appear with the technical sense identified elsewhere, as evidenced by the following passage where it has the generalmeaning of 'specification', but not the technical one as connected to tahșiș and ta 'rif/tankir: "and it is the specification of the future" (wa-huwa al-tahliș li-l-istiqbāl, Šarh II, 74).

16 This term is cited twice by Gätje $(1970: 235,239)$, who translates it similarly as "Verdeutlichung oder Explikation", i.e. 'clarification' or 'explication'. 
Know then that, with respect to indefinite expressions, the adjective conveys particularization and, with respect to definite expressions, clarification. The explanation for this is that when you say marartu bi-rajulin tawillin 'I passed by a tall man', you reduce the generality of the noun, applying it to only some of [its] species rather than to its entirety as you do not include in it any man who is not tall. This is what is meant by particularization, and it only occurs with the indefinite expression [...]. Clarification, on the other hand, occurs in definite expressions. When you say, for instance, jā'anì zaydun al-țawill 'the tall Zayd came to me', you only need the qualification when there are two men, each one of them called Zayd, and you want to make clear to the interlocutor that you are referring to thetaller one of the two. Thisis elimination of ambiguityand clarification, rather than particularization, since particularization, as we have mentioned, means to single out one part from a genus. A proper nameis a noun referring to a thing in itself; it does not signify the genus, which would make it possible to imagine its particularization (tumma i lam 'anna l-șifa tufídu fí l-nakira al-tahșīș wa-fi l-ma 'rifa al-tawdịh tafsìr hād $\bar{a}$ 'annaka 'id̄a qulta marartu bi-rajulin țawīlin kunta qad naqașta min 'umūm al-ism fa-ja'altahu yaqa'u 'alā ba'ḍ al-jins dūna kullihi min hayțu lā tudhilu man lā yakūnu țawīlan min al-rijālfíhifa-hādāa huwa l-murād biI-tahșịș wa-lā yakūnu 'illā fí l-nakira [...] wa-l-tawḍīh fị l-ma' rifa fa-huwa 'annaka 'idā qulta jā'anī zaydun al-țawīlu fa-'innaka 'innamā tahtāju 'ilā I-șifa 'ịdā kāna hunāka rajulāni kull wāhid minhumā yusammā zaydan fa'anta turīdu 'an tubayyina li-l-muhāțab 'annaka 'anayta minhumā allad̄i huwa țawīl fa-kāna dēālika 'izāla li-l-labs wa-tawḍịhan wa-lā yakūnu tahșișan li-'anna l-tahșịș kamā d̆akarnā huwa 'an nahușșa min al-jins ba'ḍahu wa-l-'alam yakūnu sman li-šay' bi- 'aynihi wa-lā yadullu 'alājins ḥattā yatașawwara fihil-tahșịș).

In doing so, al-Jurjāni is the first to be clear about the distinction to be made between tahșiș and tawdīị. We find the same two notions being used by alZamahšarī (Mufașsal 148), who writes about the adjective: "It is said that it [the qualification] is used for particularization within the indefinite expressions and for clarification within the definite ones" (wa-yuqālu 'innahā li-I-tahșiș fĩ I-nakirāt wa-li-l-tawdịh fĩ I-ma'ārif ).17 The same distribution is found in Ibn

17 Incidentally, one may note that al-Zamahšarī (Mufașșal 158) uses the same lexical root in Form II, in the shape of a conjugated verb, when he talks about the explanatory apposition: wa-wurūd al-țānì min 'ajl 'an yuwaḍ̂ịha 'amrahu. 
Yaǐiš' (d. 643/1245) commentary on the Mufașșal (Šarh II, 233), again about the adjective: "The fact is that it [the qualification] is used for particularization at the level of indefinite expressions and for clarification at the level of definite expressions, as we have mentioned" ('innahā li-l-tahșịș fĩ l-nakirāt wali-I-tawdīh fī l-ma'ārif 'alā mā ḍakarnāhu). Likewise, Ibn al-Hājib (d. 646/1249) in his 'Imlā' 'alā I-Käfiya (the autocommentary he made of his Kāfiya, which in its turn is an epitome extracted from al-Zamahšsarīs Mufașsal), uses the same pair of terms with respect to the adjective ('Imlä'48a/3; Käfiya 129): "His words 'it conveys particularization or clarification' [mean that] particularization concerns indefinite expressions and that clarification concerns definite expressions" (qawluhu wa-fāidatuhu tahșīș 'aw tawdīị fa-l-tahșịș fĩ l-nakirāt waI-tawdīh fĩ I-ma'ārif ). Finally, to conclude with the family of treatises related to the Mufașșal, Raḍi l-Dīn al-’Astarābādīi (d. 686/1287 or more likely 688/1289) states (Šarḥ III, 314):

The meaning of 'particularization' in their [i.e., the Arab grammarians'] terminology is to restrict the equivocity that occurs at the level ofind efinite expressions. Thus, when you say jä'anī rajulun șălihun 'a pious man came to me', according to the imposition of language the word rajul is applicable to all individuals of this species, and by saying șālih 'pious', you reduce the possible equivocity. According to them [the grammarians], the meaning of 'clarification' is to remove the possible equivocity occuring in definite expressions, regardless of whether or not they are proper names, as in zaydun al-älimu 'Zayd the scholar' or al-rajulu I-fäḍilu 'the virtuous man' (ma 'nā tahșị̄șișțilāhihihim taqlïlal-ištirākal-ḥaș̣ilfïl-nakirāt wa-d̄ālika 'anna rajulfí qawlika jā'anī rajulun șāliḥun kāna bi-waḍ 'al-wāḍi' muhtamalan li-kull fard min 'afrād hād lalta l-ištirāk wa-l-iḥtimāl wa-ma nā l-tawḍịh 'indahum raf' al-ištirāk alḥāșil fí l-ma ārif' 'a lāman kānat'aw lā naḥwa zaydun al-'ālimu wa-l-rajulu l-fāḍilu).

In another family of Arabic grammatical treatises, that of the Alfiyya, the term tawdịh is used in the same way by Ibn Hišām al-'Anșārī (d. 761/1360), who writes about the adjective (Sabil 416):

It conveys particularization, description, praise, blame, pity, or corroboration. The adjective conveys either particularization of an indefinite expression, as in marartu bi-rajulin kātibin 'I passed by a writing man', or clarification of a definite one, as in marartu bi-zaydinal-hayyāți'I passed by Zayd the tailor' (wa-fä idatuhu tahșiș 'aw tawdīị 'aw madḥ 'aw damm 
'aw taraḥhum 'aw tawkīd. fä 'idat al-na 't 'immā tahșīș nakira ka-qawlika marartubi-rajulin kātibin 'aw taw dịh ma rifa ka-qawlika marartu bi-zaydin al-h̆ayyāți 'aw madḥ...)18

Finally, two features of the complementary term tahșiș may be noted here. Firstly, tawdịh can be replaced by 'ị̂a $h$ h, a term derived from the same consonantal root, but derived from Form IV, which is found especially in Ibn Hišām al-'Anșārī (Sabīl 435). He states about the explanatory apposition that "of every noun we can say that it is an explanatory apposition conveying elucidation or particularization" (kull ism șaḥh al-hukm 'alayhi bi-'annahu 'ațf bayān mufĩd liI-'ị̂āḥ 'aw li-I-tahșịș). Likewise, Ibn 'Aqīl (d. 769/1367) writes (Šarh II, 57 f.): "The explanatory apposition is the frozen apposition that looks like a qualification in elucidating the element to which it is apposed [...], since it is a clarifier" (wa-atf al-bayān huwa l-tābi al-jāmid al-mušbih li-I-șifa fî 'ị̣̂āh matbūi ihi [...] li-'annahu muwaḍdih).19

Secondly, we should note two significant exceptions. The first is represented by Ibn al-'Anbārī (d. 577/1181), who writes in bāb al-wașf ('Asrār 155):

If someone asks 'what is the purpose of qualification?', he is told that it is particularization and distinction. Thus, if it is a definite expression, the purpose of qualification is particularization, because of the inherent equivocity. Don'tyou seethat there are many people called 'Zayd', or something similar, so that when we say jä'anizaydun 'Zayd came to me', it is not known which one of them we mean? Thus, when we say zaydun al-'àqilu 'Zayd the intelligent' or al-'ālimu 'the learned' or al-'adību 'the educated', or something similar, we single him out from among the others. Now, if the noun is an ind efinite expression, the purpose of qualification is distinction. Don't you see that when you say jā'anī rajulun 'a man cameto me', it is not known which man is meant, and that when you

18 Here is the translation in French by Goguyer (1887:323f.): "Il sert à particulariser, décrire, louer, blâmer, apitoyer, corroborer. Le qualificatif sert à particulariser un nom indéterminé, ex. marartu bi-rajulin kātibin, décrire l' objet d' un nom déterminé, ex. marartu bizaydin al-hayyāți". I do not choose to translate tawdịḥ by 'to describe', as Goguyer does, since 'to clarify' is more appropriate, nor to translate nakira and ma 'rifa by 'indeterminate' and 'determinate' (see above, p. 254 and n. 8).

19 Besides, this is what we read in a contemporary dictionary of grammatical terms about the explanatory apposition (Badī` Ya'qūb and 'Āṣī 1987:II, 868): "the explanatory apposition serves to clarify the term to which it is attached if it is a definite expression" (yufidu 'atf al-bayān 'ị̣̂āh matbū ihi 'in kāna l-matbū 'ma'rifa). 
say rajulun 'ãqilun 'an intelligent man', you distinguish him from those whodo not possess this qualification, and that it is not a matter of particularizing him, because by distinguishing we mean a specific entity, which was not intended here? ('in qāla qāil mā al-ġarad fï l-wașf qīla al-tahșịș wa-l-tafộil fa-'in kāna ma'rifa kāna l-garaḍ min al-wașfal-tahșịș li-'anna lištirāk yaqa 'u fîhā 'a-lā tarā 'anna l-musammīn bi-zayd wa-nahwihi kațìr fa-'idāa qāla jā'anī zaydun lā yu 'lamu 'ayyuhum yurīdu fa-'id al-'āqilu 'aw al-'ālimu 'aw al-'adību wa-mā 'ašbaha d̄ālika fa-qad ḩașșahu min ġayrihi wa-'in kāna l-ism nakira kāna l-ġaraḍ min al-wașf al-tafḍill 'alā tarā'annaka 'idā qultajāànīrajulun lamyu 'lam 'ayyrajul huwafa-'id qulta rajulun 'āqilunfa-qad faḍd daltahu 'alā man laysa lahu hādāa-l-wașf wa-lamtahușșahuli-'annāna 'nībi-I-tafḍill šay'an bi- 'aynihiwa-lamnuridhu hāhunā)

This is indeed a remarkable exception to the extent that it implies a reversal compared to all other grammarians, since tahșiș designates here what the oth-

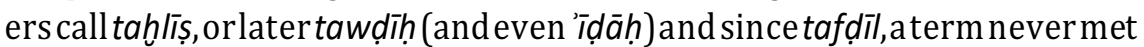
in other grammarians in the technical sense that concerns us, refers precisely to what others call tahșiss.

The second is to be found in Ibn Mālik. Indeed, whereas taw dịh is found in Ibn Hišām al-'Anșārī, as we have seen, when he is commenting Ibn Mālik, the latter explicitly proposes an other pair of terms, in which tahșiș is opposed to tawkīd. Thus, he writes (Šarḥ II, 489):

The qualification is generally used to particularize what it follows as in uhjuranna zaydan al-badī 'get away from Zayd the obscene!' and it can convey [...] the confirmation of what precedes (wa-l-na't ġăliban li-tahșịs alladīyatlūhu ka-hjuranna zaydan I-badīiwa-qad yufídu [...] tawkīd mā taqaddama).

Here, the particularity is not only the appearance of a new term. The terms appear in fact to be reversed, compared to tahșiș-tawdịh as it is found elsewhere, in particular in his commentator Ibn Hišām al-'Anșārī. This is confirmed by what Ibn Mālik writes in the commentary on his Kăfiya al-Šăfiya, since in connection with the adjective, tahșiss is used within the framework of definition, whereas tawkīd is used within the framework of indefinition (Šarh I, 520): "Particularization is like al-ši rāa al-'abūr 'Canis Minor'20 [...] and simple confir-

$\overline{20 \quad \text { Name }}$ of the constellation, see Kazimirski (1860:II, 154). 
mation is like lā tattahidū 'ilāhayni tnayni 'Take not for worship two gods, two!'” (al-tahșịș ka-l-ši rāa al-'abūr [...] wa-mujarrad al-tawkīd naḥwa lā tattahidūu 'ilāhayni țnayni). 21

On the basis of all of these sources, except for the special cases of Ibn al'Anbārīand Ibn Mālik, which however concern only the terminological level, the following technical definition may be given of tahlīș, and later of tawdịh: tahlis means to specify a definite term by another one, itself definite, within the framework of a qualification in the broad sense, that is to say an attributive adjective (al-rajul al-țawīl), including a relative sentence (al-rajul alladī yaktubu risāla), or an explanatory apposition ('aqsama bi-I-Lāhi 'abū ḥafsin 'umarin). We note the asymmetry between this definition and that of tahșiș (seeabove), sinceannexation isnotmentioned in the definition of tahliss.

\subsection{Ta rîf}

Among the authors using tahșiș, the complementaryterm to it within the special framework of annexation, is not tahliș nor tawdịh, as we have seen within the framework of (broad) qualification, rather, it is ta' rif. Thus, Ibn Jinni writes (Hașā'iș II, 267): "It has been said that the purpose of annexation is only to define or to particularize" (qïla li-'anna l-garaḍ̂i l-'iḍ̄âfa 'innamā huwa l-ta'riff wa-l-tahșișs). Here, the pair of terms consists of ta rîf and tahșiș and, therefore, in annexation ta' rîf seems to be to tahșiș what tahliș is to tahșịșin qualification. Accordingly, ta 'rif is in a situation of structural homology with tahlīs. Ibn Jinnī says elsewhere (Sirr II, 37) that "annexation imparts definition and particularization" (al-'ị̣āfa tuksibu l-ta 'rīf wa-l-tahșīṣ).

Ibn Mālikusesthe samepairofterms, butisclearerabouttheidentity of the terms involved from the point of view of definiteness (Sarh I,408):

All of this belongs to those things whose annexation is semantic, real, and pure, sinceit has the effect of defining the firstterm in an annexation, if the second term is a definite expression, and of particularizing the first term, if the second is an indefinite one ( $f a-h a \bar{a} d \bar{a}$ kulluhu mimmō 'iḍāfatuhu ma 'nawiyya wa-ḥaqīaiyya wa-maḥ̣ li-'annahā mu'ațtira fĩ Imuḍāf ta 'rīfan 'in kāna l-țānī ma rifa wa-tahșịșan 'in kāna l-țānīnakira).

He is followed in this by Ibn Hišām al-'Anșārī (Sabīl 377 f.):

$21 \quad$ Q.16/51. Here, tawkīd applies to a definite expression ('ilähayn), qualified by an element itself indefinite (ịnnayn), where the other grammarians use tahlīṣ-tawdīịh. 
Itis called semantic annexation because it defines or particularizes [...]. It is definition if the second term of annexation is a definite expression, as in gulāmuzaydin 'Zayd's servant', and it is particularization if it is an indefinite one, as in gulāmu mra'atin 'a woman's servant' [...]. It [i.e. the 'iḍ̂afa lafziyya 'formal annexation'] conveys neither definition nor particularization (tusammā ma 'nawiyya li-'annahā li-l-ta 'rîf'awal-tahșiș [...] wa-huwa al-ta 'rīf 'in kāna l-muḍāf 'ilayhi ma rifa naḥwa gu lāmu zaydin wa-l-tahșịș 'in kānal-muḍāaf' ilayhinakira ka-g̈ulāmumra'atin [...] wa-lā tufídu ta' 'ī̄fan wa-lā tahșịșan)

Likewise, Ibn `Aqīl (Šarḥ I, 368 f.) states:

Pure [annexation] is what is not like this. It conveys the first term of the annexation with particularization if the second term of the annexation is an ind efinite expression, as in hā $\underline{d} \bar{a} \dot{g} u l a ̄ m u m r a ' a t i n$ 'this is a woman's servant', and [it conveys] definition if the second term of annexation is a definite expression, as in hādō gulāmu zaydin 'this is Zayd's servant'. Thus, it [the first class, i.e. pure annexation] conveys particularization or definition (wa-l-maḥ̣a [al-'iḍāfa] mā laysat ka-d̄ālika wa-tufídu l-ismal-'awwal tahșișan 'in kāna l-muḍāf 'ilayhi nakira naḥwa hāḍā gulāmu mra'atin wata'rîfan 'in kāna l-muḍāf 'ilayhi ma rifa naḥwa hāḍā gulāmu zaydin [...] fa-yufidu tahșișan 'awta rîfan)

The same view on annexation in found in al-Zamahšsarī (Mufașșal 119).

Annexation of a noun to a noun is of two types, semantic and formal. Semantic annexation conveys definition, as in dāru 'amrin "Amr's house', and [it conveys] particularization, as in ġulämu rajulin 'a man's servant' ('ịdāfatal-ism li-sm 'alā darbayn ma 'nawiyya wa-lafz̧iyyafa-l-ma'nawiyya mā 'afāda ta 'rîfan ka-qawlika dāru 'amrin' 'aw tahșịșan ka-qawlika gulāmu rajulin)

Ibn Ya īš (Šarh II, 126) says the same about annexation, and so do Ibn al-Hājib (Kāfiya 122) and Raḍi l-Dīn al-'Astarābādī (Šarḥ I, 202; II, 238 f.). Finally, we find the same view in later authors like al-Jārburdì (d. 746/1346), who states (Muġni 35):

Semanticannexation conveys definition of the first term of the annexation when it is annexed to a definite expression, like gulämuzaydin 'Zayd's servant', and particularization of it when it is annexed to an indefinite 
expression, like ġulāmu rajulin 'a man's servant' (wa-I-'idâffa al-ma 'na-

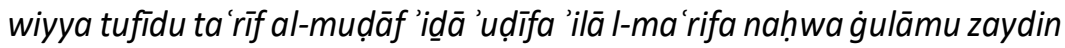
wa-tahșișahu 'ịda 'udịifa 'ilā I-nakira nahwa ġulāmu rajulin).

Likewise, al-Sayyid al-Šarîf (Ta rífāt 32) defines annexation asfollows: "annexation is joining two nouns in such a way that it conveys definition or particularization" (al-'iḍāfa hiya imtizōj ismayn 'alā wajh yufidu ta rīfan 'awtahșișan).

Thus, it appears that within the framework of annexation, the terminological pair is indeed ta 'rif/tahșiss, of which the former corresponds to theannex-

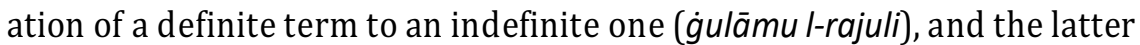
to the annexation of an indefinite term to an ind efinite one (g்ulämu rajulin). Accordingly, in annexation ta 'riff is to tahșīș what tahlīșis to tahșiș in qualification. Moreover, the term tahșīs, used for both annexation and (broad) qualification in the ind efinite framework, the terms tahlișs-tawdīịn-'ịdāḥ used exclusively for (broad) qualification in the definite framework, and theterm ta' rif used exclusively for annexation, appear to be as many forms of 'determination', the last mentioned case conveying definition and determination at the same time. At this point, no single term seems therefore to express the concept of determination exclusively; rather, this concept is distributed between tahșiș, on the one hand, and tahliș-tawdīịh (and, more marginally, 'ị̣āh h), on the other.

Takmil, or Completion as 'Determination'

There remains a final term to be studied in relation to the categories of definition and indefinition (ta' rîf/tankirr). Ibn Hišām al-'Anșārī is apparently the first to subsume explicitly under the term of takmil 'completion'22 the processes of tawḍiḥ and tahșịș, since he writes ('Awḍh III, 223):

The coordinated appositive and the permutative are excluded, by the restriction of completion. [...] What is meant by 'what completes' is what clarifies a definite expression, such as jā'a zaydun al-tājiru 'Zayd the merchant came' or al-tājiru 'abūhu 'whose father is the merchant', and what particularizes an indefinite expression, such as jā'ani rajulun tājirun 'a merchant man came to me' or tājirun 'abūhu 'whose father

22 The term mukammil is also found in Ibn al-Dahhān (d. 569/1174), Gurra II, 854, in connection with 'aț al-bayān. 
is a merchant' ( fa-haraja bi-qayd al-takmïl al-nasaq wa-l-badal [...] waI-murād bi-I-mukammil al-muwaḍḍị li-l-ma'rifa ka-jā'a zaydun al-tājiru 'aw al-tājiru 'abūhu wa-I-muhașșiș li-l-nakira ka-jä̀anī rajulun tājirun 'aw tājirun 'abūhu)

It thus appears that takmil represents indeed the generic term and hyperonym of both processes of tawdīth and tahșiss. It seems that the first appearance of takmil (in the technical sense as well as absolutely) is found in Ibn Mālik. It appears in connection with the adjective ( $n a^{\prime} t$ ), on the one hand, and with the explanatory apposition ('att al-bayān), on the other: "except that the adjective leads to this completion because it indicates a meaning in the qualified element [...]; the qualification is then what completes the term it follows, and the completed item is what is followed [by the adjective]" ('illā 'anna l-na't yuwașșilu 'ilā dōalika l-takmïl bi-dalālatihi 'alā ma'nan fĩ l-man'ūt [...] fa-l-na't al-mukammil matbū'ahu [...] wa-I-mukammal matbū'uhu, Šarh I, 516) and "the explanatory apposition is an appositive term which follows the course of the qualification in terms of completion of the element it follows" ('ațfal-bayān tābi 'yajrī majrā I-na't fí takmïl matbū ihi, Šarh I, 532).

The term takmillseems to be used only by these two authors, but it is an interesting term because it encompasses tahșiș and tawdịh. This applies, however, only to the framework of (broad) qualification, not to that of annexation. This prompts us to distinguish, under tahșiș, that which is opposed and com-

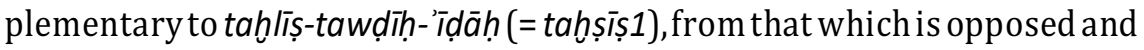
complementary to ta' rîf (= tahșīș2).

\section{Conclusion}

As I have noted elsewhere, though less precisely (Sartori 2018), tahșiș is an intersection to tankïr and ta'rîf. As a matter of fact, if the process of tahșiș applies indeed to an indefinite noun, it does not fall under indefiniteness.23 However, it does not belong to the domain of definition ( ta $^{\prime} r i \bar{f}$ ) either, since for the latter it constitutes the complementary term. The question arises whether this makes it an equivalent of 'determination' (whether almost or partial determination, as

23 As may be seen, among other authors, in Ibn Jinnī (Hașāișis II, 447): "and also, the fact is that nunation indicates indefinition and that annexation is instituted for particularization, so how can you combine them despite what we have remarked about them?" (wa-'aydan

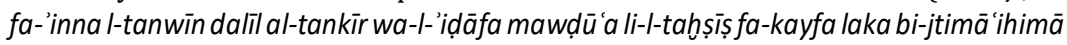
ma'a mā dakarnā min ḥālihimā). 
proposed by Reckendorf or Wright) or a weak definition (according to Carter). It seems that this question should be answered in the negative. Rather, it ought to be reaffirmed that the couple ta'rif/tankir is indeed that of definition/indefiniteness. Under this pair, while no term seems to exist in the Arabic grammatical metalanguage to signify 'indetermination', the second member of the pair, 'determination', seems to correspond to many Arabic terms. It is tahșiș 'particularization' within the framework of indefiniteness, and tahliș-tawdịh (and even, but more marginally, 'īdā $h$ ) 'specification', 'clarification' within that of definition, butalso ta 'rif 'definition' for the particular case of annexation within the definite framework. Only one author, Ibn Hišām al-'Anșārī, assigns a special sta-

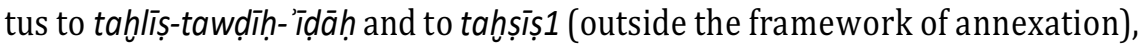
bringing together these terms under the label of takmil' 'completion'.

As for ta' rif understood as definition, within the framework of annexation it is complementary to tahșișs. It then applies to an indefinite term within the annexation construct, which is transferred by it from indefiniteness to definition.24 Therefore, Arab grammarians felt that something else than the mere opposition tankir/ta'rif was at work. Obviously without using terms equivalent to our pair 'indetermination/determination', they came close to 'determination' through tahșiș 'particularization', tahlīṣ 'specification', tawdīịn- 'ịdāḥ 'clarification-elucidation' and takmil 'completion'. In the absence of any other, takmil seems to be best able to evoke a generic form of 'determination', understood as a predicative determination.25 This is represented in Figure 1.

This is opposed to Kouloughli's (2001:40) reading, for whom specification (particularization-tahșisş) is not determination, and for whom kalb in expressions like kalbu zaydin 'Zayd's dog' is definite and indeterminate, while in expressions like kalbu șaydin 'a hunting dog' it is indefinite and indeterminate. We should rather consider them both determinate, accepting that tahșiș within the domain of annexation is indeed a determination. The schema proposed by Kouloughli would therefore be replaced by the one in Figure 2.

$24 \quad$ Notethatanindefinite expressioncanbe determinate (a tallman, where man is determinate by a (quantification) and tall (qualification)) or indeterminate ( $m a n$ ), while a definite expression is necessarily determinate (the man). 


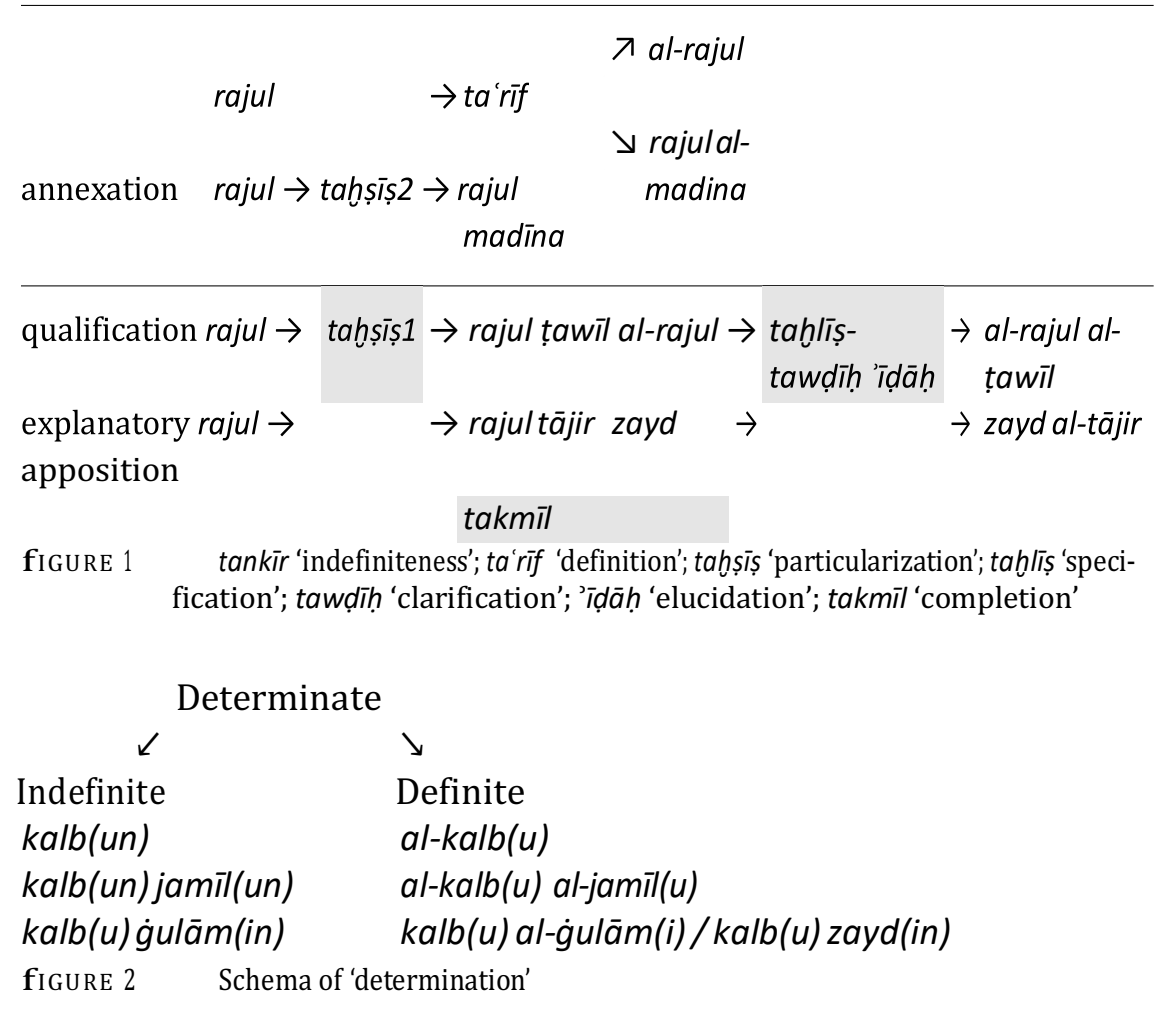

\section{Bibliographical References}

\section{A PrimarySources}

'Astarābādī, Šarh = Raḍi l-Dīn Muḥammad ibn al-Ḥasan al-'Astarābādīi, Šarh Kāfiyat Ibn al-Hājib. Ed. by 'Imīl Badī' Yađqūb. 5 vols. Beirut: Dār al-Kutub al-'Ilmiyya, 1998.

Ibn 'Aqīl, Šarḥ = Bahā' al-Dīn 'Abdallāh ibn 'Abd al-Raḥmān ibn 'Abdallāh ibn Muḥammad Bahā' al-Dīn al-Qurašī al-Hāšimī al-'Aqīlī al-Hamdānī al-Miṣrī Ibn 'Aqīl, Šarḥ Ibn 'Aqīl 'alā 'Alfiyyat Ibn Mālik. Ed. 'Īmīl Badī' Ya'qūb. 7th ed. 2 vols. Beirut: Dār alKutub al-'Ilmiyya, 2010.

Ibn al-Dahhān, Gurra = 'Abū Muḥammad Sa'īd ibn al-Mubārak ibn 'Alī al-'Anșārī alma'rūf bi-Ibn al-Dahhān al-Bağdādī, al-Gurra fĩ šarh al-Luma' min 'awwal bāb 'inna wa-'ahawātihā 'ilā 'āhir bāb al-'ațf. Ed. by Farīd 'Abd al-'Azīz Al-Zālim al-Sulaym. 2 vols. Riyadh: Dār al-Tadmūriyya, 2011.

Ibn al-Ḥājib, 'Imlā' = Jamāl al-Dīn 'Abū 'Amr 'Uțān ibn 'Umar ibn 'Abī Bakr Ibn alḤājib al-Miṣrī al-Dimašqī al-Mālikī, al-'Imlā' 'alā I-Kāfiya fī l-naḥw. Ed. by Manuel Sartori. [unpublished], 2012. 
Ibn al-Ḥājib, Kāfiya = Jamāl al-Dīn 'Abū 'Amr 'Uțmān ibn 'Umar ibn ’Abī Bakr Ibn alHājib al-Miṣrī al-Dimašqī al-Mālikī, al-Kāfiya fīl-naḥw. Ed. by Ṭāriq Najm ‘Abdallāh. Jeddah: Maktabat Dār al-Wafä', 1986.

Ibn al-'Anbārī, 'Asrār = Kamāl al-Dīn 'Abū l-Barakāt 'Abd al-Raḥmān ibn Muḥammad ibn 'Ubayd Allāh al-'Anșārī al-'Anbārī, 'Asrār al-'arabiyya. Ed. by Muḥammad Ḥusayn Šams al-Dīn. Beirut: Dār al-Kutub al-'Ilmiyya, 1997.

Ibn Fāris, Șạhibì = 'Abū l-Ḥusayn 'Aḥmad Ibn Fāris ibn Zakariyā' al-Qazwīnī al-Rāzì, alȘāḥibĩ fĩ fiqh al-luġa al-'arabiyya wa-masāilihā wa-sunan al-'Arab fĩ kalāmihim. Ed. by ’Ahmad Hasan Basj. Beirut: Dār al-Kutub al-'Ilmiyya, 1997.

Ibn Jinnī, Hașā iș = 'Abū l-Fatḥ 'Uțān Ibn Jinnī al-Mawșilī, al-Hașāi iṣ. Ed. by 'Abd alHamīd Hindāwī. 3rd ed. 3vols. Beirut: Dār al-Kutubal-'Ilmiyya, 2008.

Ibn Jinnī, Sirr = 'Abū l-Fatḥ 'Uțmān Ibn Jinnī al-Mawșilī, Sirr șinā'at al-'i 'rāb. Ed. by Muḥammad Ḥasan Muhammad Ḥasan 'Ismāēil and 'Ahmad Rušdī Šahāta ‘Āmir. 2nd ed. 2 vols. Beirut: Dār al-Kutub al-'Ilmiyya, 2007.

Ibn Hูarūf, Šarh = 'Abū l-Ḥasan 'Alī ibn Muhammad ibn 'Alī Ibn Hูarūf al-'Išbīlī, Šarḥ Jumal al-Zajjājī. Ed. by Salwā Muḥammad 'Umar 'Arab. Mecca: Jāmi'at 'Umm alQurā, 1998.

Ibn Hišām, Sabīl = Jamāl al-Dīn 'Abū Muhammad 'Abdallāh ibn Yūsuf al-'Anșārī Ibn Hišām, Sabīl al-hudā 'alā šarh Qațr al-nadā wa-ball al-șadā wa-ma'a-hu Risāla fĩ madḥ al-naḥw. Ed. by Muhammad Muhyī l-Dīn 'Abd al-Ḥamīd and 'Abd al-Jalīl al'Atā al-Bakrī. Damascus: Maktabat Dār al-Fajr, 2001.

Ibn Hišām, 'Awḍaḥ = Jamāl al-Dīn 'Abū Muḥammad 'Abdallāh ibn Yūsuf al-'Anșārī Ibn Hišām, 'Awḍạ̣ al-masālik ilā 'Alfiyyat Ibn Mālik. Ed. by H. al-Fāhūūī. 4 vols. Beirut: Dār al-Jīl, 1989.

Ibn Mālik, Šarh = Jamāl al-Dīn 'Abū 'Abdallāh Muḥammad ibn 'Abdallāh ibn 'Abd Allāh al-Ṭāī al-Jayyānī al-'Andalusī Ibn Mālik, Šarh al-Kāfiya al-Šāfiya. Ed. by 'Alī Muhammad Mu'awwaḍ and 'Ādil 'Ahmmad 'Abd al-Mawjūd. 2nd ed. 2 vols. Beirut: Dār alKutub al-'Ilmiyya, 2010.

Ibn Ya'ī̌s, Šarh = Muwaffaq al-Dīn 'Abū l-Baqā’ Yacīš ibn 'Alī Ibn Yacī̌s al-'Asadī al-Ḥalabī, Šarh al-Mufașșal li-l-Zamahšarī. 2nd ed. 6 vols. Ed. by 'Imīl Badī' Ya'qūb. Beirut: Dār al-Kutub al-'Ilmiyya, 2011.

Ibn 'Ușfūr, Šarḥ = 'Abū l-Ḥasan 'Alī ibn al-Mu'min ibn Muḥammad al-Ḥaḍramī al-'Išbīlī Ibn 'Ușfūr, Šarḥ Jumal al-Zajjājī. Ed. by Fawwāz al-Ša'cār and 'Īmīl Badī' Ya'qūb. 3 vols. Beirut: Dār al-Kutub al-'Ilmiyya, 1998.

Jārburdī, Muġnī = Faḩr al-Dīn 'Abūl-Makārim 'Aḥmad ibn al-Ḥasan ibn Yūsuf alJārburdī al-Šāficī, al-Muginífĩ 'ilmal-naḥw. Ed. by Qāsim al-Mūšš ’Abū Muhammad 'Anas. Beirut: Dār Ṣādir and Istanbul: Maktabatal-'Iršād, 2007.

Jurjānī, Dalāill = 'Abū Bakr 'Abd al-Qāhir ibn 'Abd al-Raḥmān ibn Muḥammad alJurjānī, Dalā’il al-'íjāz. Ed. by Muhammad al-Tunjī. 3rd ed. Beirut: Dār al-Kitāb al'Arabī, 1999. 
Jurjānī, Muqtașid = 'Abū Bakr 'Abd al-Qāhir ibn 'Abd al-Raḥmān ibn Muḥammad alJurjānī, al-Muqtașidfíšarḥ risālatal-'Ị̣āḥ. Ed. byal-Širbīnī Šarīda. 2 vols. Cairo: Dār al-Hadīt, 2009.

Jurjānī, Šarḥ = 'Abū Bakr 'Abd al-Qāhir ibn 'Abd al-Raḥmān ibn Muḥammad al-Jurjānī, Šarḥ al-jumal fī l-naḥw. Ed. by Halīl 'Abd al-Qādir 'Īsā. 10TH ed. Beirut: Dār Ibn Hazm and Amman: al-Dār al-'Utmāniyya, 2011.

Mubarrad, Muqtaḍab = 'Abū l-'Abbās Muhammad ibn Yazīd al-Mubarrad, al-Muqtaḍab. Ed. by Ḥasan Hamad and 'Imīl Badì Ya'qūb. 5 parts in 3 vols. Beirut: Dār al-Kutub al-'Ilmiyya, 1999.

Qazwīnī, 'Ṭ̣̂aḥ = Jalāl al-Dīn Muhammad ibn 'Abd al-Raḥmān al-Šāficī al-Dimašqī al-

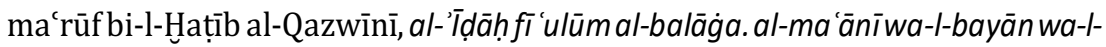
badī'.Ed. by'Ibrāhīm Šams al-Dīn. Beirut: Dāral-Kutub al-'Ilmiyya, 2003.

al-Sayyid al-Šarīf, Ta'rīfāt = 'Alī ibn Muḥammad ibn 'Alī al-Sayyid al-Šarīf al-Ḥusaynī alJurjānīal-Ḥanafī, al-Ta rî̄āt.Ed. MuḥammadBāsil 'Uyūnal-Sūd. 2nd ed. Beirut: Dār al-Kutub al-'Ilmiyya, 2003.

Zajjājī, Lāmāt = ’Abū l-Qāsim 'Abd al-Raḥmān ibn 'Isḥāq al-Nahāwandī al-Zajjājī, Kitāb al-lāmāt. Ed. by Māzin al-Mubārak. 2nd ed. Beirut: Dar Șādir, 1992.

Zamahš̌arī, Mufașșal = Jār Allāh 'Abū l-Qāsim Maḥmūd ibn 'Umar ibn Muhammad ibn 'Aḥmad al-Hुwārizmī al-Zamahššrī, al-Mufașșal fĩ șan'at al-'írāb. Ed. 'Īmīl Badī' Ya'qūb. Beirut: Dār al-Kutub al-'Ilmiyya, 1999.

\section{B Secondary Sources}

Alosh, Mahdi. 2005. Using Arabic: A guide to contemporary usage. Cambridge: Cambridge University Press.

Badawi, El-Said, Michael G. Carter, and Adrian Gully. 2004. Modern written Arabic: A comprehensive grammar. London: Routledge.

Badī‘ Ya'qūb, 'Īmīl and Mišāl ‘Āṣī. 1987. al-Mu'jam al-mufașșal fīl-lug̉a wa-l-'adab. 2 vols. Beirut: Dār al-'Ilm li-l-Malāyīn.

Blachère, Régis and Maurice Gaudefroy-Demombynes, Maurice. 1975. Grammaire de l' arabe classique (morphologie et syntaxe). 3rd. revised ed. Paris: Maisonneuve et Larose.

Brustad, Kristen E. 2000. The syntax of Spoken Arabic: A comparative study of Moroccan, Egyptian, Syrian and Kuwaiti dialects. Washington, D.C.: Georgetown University Press.

Buckley, Ronald Paul. 2004. Modern Literary Arabic: A reference grammar. Beirut: Librairie du Liban.

Cantarino, Vicente. 1974-1975. Syntax of modern Arabic prose. 2 vols. Bloomington and London: Indiana University Press.

Carter, Michael G. 1981. Arab linguistics: An introductory Classical text with translation and notes. Amsterdam: J. Benjamins. 
Carter, Michael G. "Ta'rif". Encylopaedia of Islam, 2nd ed., X, 241A-B. Leiden: E.J. Brill.

El-Ayoubi, Hashem, Dieter Blohm and Wolfdietrich Fischer. 2010. Syntax derarabischen Schriftsprache der Gegenwart. II. Die Verbalgruppe. Wiesbaden: 0. Harrassowitz.

Fleisch, Henri. 1961. Traité de philologie arabe. I. Préliminaires, phonétique, morphologie nominale. Beirut: Imprimerie catholique.

Fleisch, Henri. 1979. Traité de philologie arabe. II. Pronoms, morphologie verbale, particules. Beirut: Dar al-Machreq.

Fleisch, Henri. 1986. "Iḍăfa". Encyclopaedia of Islam, 2nd ed. III, 1008A-1009A. Leiden: E.J. Brill.

Forbes, Duncan. 1863. Grammar of the Arabic language intended more especially for the use of young men preparing for the East India civil service; and also for the use of selfinstructing students in general. London: Wm. H. Allen \& Co.

Gätje, Helmut. 1970. "Zum Begriff der Determination und Indetermination im Arabischen". Arabica 17.225-251. [Available at: http://www.jstor.org/stable/4055880].

Hassanein, Azza. 2006. Modern Standard Arabic grammar: A concise guide. Cairo and New York: The American University Press in Cairo.

Heselwood, Barry and Janet Watson. 2015. "The Arabic definite article: A synchronic and historical perspective". Arabic and Semitic linguistics contextualized: A festschrift for Jan Retsö, ed. by Lutz Edzard, 157-176. Wiesbaden: 0. Harrassowitz.

Holes, Clive. 2004. Modern Arabic: Structures, functions and varieties. 2nd revised ed. Washington, D.C.: Georgetown University Press. (1ST ed. 1995.) Howell,

Mortimer Sloper. 1911 [1880-1911]. A grammar of the Classical Arabic language, translated and compiled from the works of the most approved native or naturalized authorities. 4 vols. Allahabad.

Hoyt, Frederick M. 2009. "Specificity". Encyclopedia of Arabic language and linguistics, ed. by Mushira Eid et al., IV, 315-320. Leiden: E.J. Brill.

Imbert, Frédéric. 2008. L'arabe dans tous ses états! La grammaire arabe en tableaux. Paris: Ellipses.

Kazimirski, Adrien de Biberstein. 1860. Dictionnaire arabe-français. 2 vols. Beirut: Maisonneuve.

Kouloughli, Djamel Eddine. 1994. Grammaire de l'arabe d'aujourd' hui. Paris: Pocket, "Langues pour tous".

Kouloughli, Djamel Eddine. 2001. "Sur le statut linguistique du tanwīn: Contribution à l' étude du système déterminatif de l' arabe". Arabica 48.20-50. [Available at: http:// www.jstor.org/stable/4057589].

Larcher, Pierre. 1991. “D’ une grammaire l' autre: Catégorie d' adverbe et catégorie de maf 'ūl muțlaq". De la grammaire de l' arabe aux grammaires des arabes, ed. by Pierre Larcher, Bulletin d'Études Orientales 43.139-159. [Available at: http://www.jstor.org/ STABLE/41608973]. 
Larcher, Pierre. 2011. "Un texte arabe sur le métalangage". A festschrift for Nadia Anghelescu, ed. by Andrei A. Avram et al., 306-317. Bucharest: Editura Universităţii din Bucureşti.

Larcher, Pierre. 2014. Linguistique arabe et pragmatique. Beirut: Presses de l'Ifpo.

McCarus, Ernest N. 2007. English grammar for students of Arabic: The study guide for those learning Arabic. Ann Arbor: The Olivia and Hill Press.

Morais Barbosa, Jorge. 1998. "Détermination épithétique et détermination prédicative". La Linguistique 34:2.15-20.

Neyreneuf, Michel and Ghalib Al-Hakkak. 1996. Grammaire active de l'arabe. Paris: Le Livre de Poche.

Palmer, Edward Henry. 1874. A grammar of the Arabic language. London: Wm. H. Allen \& Co.

Reckendorf, Hermann. 1921. Arabische Syntax. Heidelberg: Carl Winter's Universitätsbuchhandlung.

Retsö, Jan. 1986. "State, determination and definiteness in Arabic: A reconsideration". Orientalia Suecana 33-34.341-346.

Ryding, Karin C. 2005. Areference grammarofModern Arabic. Cambridge:Cambridge University Press.

Ryding, Karin C. and Kees Versteegh. 2007. "'ldāfa". Encyclopedia of Arabic language and linguistics, ed. by Mushira Eid et al., II, 294-298. Leiden: E.J. Brill.

Sartori, Manuel. 2018. "Origin and conceptual evolution of the term tahșīs in Arabic grammar". Foundations of Arabic linguistics. III. The development of a tradition: Continuity and change, ed. by Georgine Ayoub and Kees Versteegh, 203-228. Leiden: E.J. Brill.

Schulz, Eckehard et al. 1996. Lehrbuch des modernen Arabisch. Berlin and Munich: Langescheidt KG. (English transl., Standard Arabic. An elementary-intermediate course, New York: Cambridge University Press, 2008 [2000].)

Silvestre de Sacy, Antoine-Isaac. 1831. Grammaire arabe à l'usage des élèves de l'école spéciale des langues orientales vivantes, avec figures. 2nd revised ed. 2 vols. Paris: Imprimerie royale. (3rd ed., revised by L. Machuel. Tunis: Institut de Carthage, 1904.) Socin, Albert. 1885. Arabische Grammatik: Paradigmen, Litteratur, Chrestomathie und Glossar. Karlsruhe and Leipzig: Reuther.

Troupeau, Gérard. 1976. Lexique-index du Kitāb de Sïbawayhi. Paris: Klincksieck.

Troupeau, Gérard. 1993. "Na't" Encyclopaedia of Islam, VII, 1034a. Leiden: E.J. Brill. [Available at: http://referenceworks.brillonline.com.lama.univ-amu.fr/entries/ encyclopedie-de-l-islam/nat-SIM_5848].

Vernier, Donat. 1891. Grammaire arabe composée d'après les sources primitives. 2 vols. Beirut: Imprimerie catholique.

Wensinck, Arent Jan. 1931. "The article of determination in Arabic". Mededeelingen der Koninklijke Akademie van Wetenschappen, Afdeeling Letterkunde 71, serie A, no. 3. 
Wright, William. 1996. A grammar of the Arabic language. 2 vols. Repr., Beirut: Librairie du Liban. (1ST ed., 1859-1862; 3rd ed., revised by W. Robertson Smith and M.J. de Goeje. Cambridge: Cambridge University Press, 1896-1898.) 